\title{
IV. РЕЦЕНЗIÏ
}

ISSN 2411-4758 (Print) 2518-1602 (Online)

Native word in ethnocultural dimension, Drohobych, Posvit, 2021, pp. 205-212.

DOI: https://doi.org/10.24919/2411-4758.2021.213140

УДК 811.161.2’373.3(477)

\section{АСТІОНІМИ УКРАЇНИ: ОНОМАСТИЧНИЙ ТА ЛІНГВОКУЛЬТУРОЛОГІЧНИЙ АСПЕКТИ}

стаття-рецензія на монографію: Котович, В.В. (2020). Ойконімія

Украӥни як лінгвокультурний феномен. Дрогобич : Посвіт.

\section{Світлана ГІРНЯК,}

доктор філологічних наук, дочент кафедри філологічних дисииплін та методики їх викладання у початковій школі Дрогобицького державного педагогічного університету імені Івана Франка s.girnjak10@gmail.com

ORCID: http://orcid.org/0000-0001-7264-0312

Research ID: I-3030-2018 http://www.researcherid.com/rid/I-3030-2018

Cтаттю подано до редколегіï/The article is submitted to the editorial board:30.09.2020.

Cтаттю опубліковано/The article is published: 22.02.2021.

У статті-рецензії здійснено аналіз монографії В. Котович «Ойконімія Украӥни як лінгвокультурний феномен», щчо побачила світ 2020 року. У розвідиі досліджено назви поселень України в контексті ономастики та лінгвокультурології; змодельовано лінгвокультурологічні портрети сучасних астіонімів України. Кожен з астіонімів авторка розглядає як згорнутий лінгвокультурний текст, закодування якого відбулося в часі присвоєння поселенню імені, а прочитання здійснюється впродовж усіх періодів його побутування. Дослідниия доводить, щцо назви сучасних українських міст виразно відтворюють дух і віяння епохи, яка покликала їх до життя, проєктуючи назвоцентричні процеси на формування іменотворчого колориту інших поселень.

Здійснене дослідження дало підстави автория монографії висновувати про ойконімний простір Украӥни як лінгвокультурний феномен, одиниці якого слугують джерелом пізнання культури народу, його менталітету та національного характеру.

Ключові слова: ономастика; лінгвокультурологія; ойконімія; астіокультуроніми; ойконімний простір. 
ASTIONIMS OF UKRAINE: ONOMASTIC AND LINGUOCULTURAL ASPECTS

review of the monograph: Kotovych, V. V. (2020). Oikonims of Ukraine as a linguocultural phenomenon. Drohobych : Posvit.

\section{Svitlana HIRNIAK,}

Doctor of Philology, Associate Professor of the Department of Philological Sciences and Methods of Teaching in Elementary School, Drohobych Ivan Franko State Pedagogical Universitys.girnjak10@, gmail.com

The article-review analyzes the monograph by V. Kotovych «The oikonymy of Ukraine as a linguocultural phenomenon» which was published in 2020. The names of the settlements of Ukraine in the context of onomastics and linguoculturology are researched in the work; linguocultural portraits of modern astionyms of Ukraine are modeled. The author considers each of the astionyms as a condensed linguistic and cultural text, the coding of which took place at the time of assigning a name to the settlement and the reading is carried out during all periods of its existence. The researcher proves that the names of modern Ukrainian cities clearly convey the spirit and trends of the era that called them to life, projecting name-centric processes to form the name-forming coloring of other settlements.

The conducted research gave grounds to the author of the monograph to conclude about the oikonymic space of Ukraine as a linguocultural phenomenon, the units of which serve as a source of knowledge of the culture of the nation, its mentality and national character.

Key words: onomastics; linguoculturology; oikonymy; astioculturonyms; oikonymic space.

Мова завжди була чинником ідентифікації народу. Вона розвивається в суспільстві, залежить від історичних умов побутування етносу, а отже, не може існувати без людей, які сприяють її розвитку та становленню на різних історичних етапах. Беззаперечним $€$ факт, що мова є символом і захистом нації.

Монографія В. Котович написана на актуальну тему, оскільки «продиктована необхідністю проаналізувати ономастичні явища 3 погляду лінгвокультурології, здійснити перехід від ономастики екстенсивної, системно-структурної, «іманентної», до антропоцентричної, яка розглядає мовні номінації в тісному зв'язку з людиною, їі мисленням, духовно-практичною діяльністю. Одні назви поселень збережено з прадавніх часів, інші змінювалися протягом періоду свого побутування фонетично, морфемно, граматично, лексично, проте в 
кожній із них відбито матеріальну та духовну культуру тієї епохи, яка їх народила» (с. 8).

У вступі схарактеризовано важливі для дослідниці розвідки 3 поля ономастики (А. Білецького, Д. Бучка, С. Вербича, О. Карпенко, Ю. Карпенка, В. Лучика, О. Суперанської, С. Отіна, В. Ташицького, Р. Шрамека, В. Шульгача та ін.) та лінгвокультурології (Н. Арутюнової, Є. Бартміського, В. Жайворонка, В. Кононенка, В. Маслової, М. Толстого, С. Толстої та ін.), а також роботи тих учених, які, вивчаючи різні класи онімів, обгрунтували методологію й методику дослідження українського ойконімікону в лексико-семантичному, структурно-словотвірному й етимологічному аспектах і на чиї праці щонайперше вона покликається.

У вступі В. Котович обгрунтувала актуальність дослідження, визначилася $з$ його метою: «здійснити ономастичний та лінгвокультурологічний аналізи ойконімного простору України шляхом декодування лінгвальної та позалінгвальної інформації, прихованої за кожною 3 досліджуваних одиниць, яка уможливлює співвіднесеність поверхневої структури ойконіма 3 його глибинною суттю, тобто з культурою» (с. 10 - 11), окреслила завдання, вирішення яких передбачає досягнення поставленої мети. Запрезентовані тут й інші обов'язкові атрибути - об'єкт і предмет, джерельна база та методика дослідження, наукова новизна, теоретичне і практичне значення тощо.

Монографія складається зі вступу, чотирьох основних розділів 3 підрозділами, висновків, переліку умовних позначень, списку джерел (157 найменувань), списку літератури (605 найменувань). Загальний обсяг роботи - 448 сторінок, основний зміст роботи викладено на 392 сторінках.

Перший розділ роботи - теоретико-методологічний. Це засвідчує його назва «Теоретично-методологічна база ономастико-культурологічного дослідження ойконімного простору України» та зміст підрозділів. У ньому розкрито історико-географічний аспект аналізу назв населених пунктів як підгрунтя лінгвокультурологічного їх потрактування; розглянуто український ойконімний простір як об'єкт ономастичних студій; окреслено вектори взаємодії лінгвокультурології та ономастики; схарактеризовано методи лінгвокультурологічного опрацювання назв поселень; запрезентовано базові поняття та терміни здійсненого дослідження.

В. Котович акцентує увагу на тісних зв’язках історії, географії та мовознавства під час аналізу назв поселень і зазначає, що «географія та історія накладають особливий відбиток на ономастику кожної 
мови, забезпечуючи їі неповторність та спрямовуючи історико-географічні студії в річище культуроцентричних, переносячи дослідницький інтерес з об'єкта пізнання на суб'єкт - людину, яка номінує довкілля крізь призму свого національно-етнічного бачення» (с. 22), а також наголошує, що краєзнавчо-етнографічні праці важливо розглядати як невід'ємний внесок у лінгвокультурологічне осягнення онімного простору.

Дослідниця зауважує, що активне становлення ономастики в Україні припадає на середину минулого століття, проте вважаємо за доцільне зазначити, що на середину минулого століття припадає становлення ономастики в сучасному їі вигляді - як самостійної лінгвістичної дисципліни зі своїм предметом і методами аналізу фактичного матеріалу, однак чи не першим ономастом можна вважати Памва Беринду з його «Лексиконом славенороским і імен толкованієм», а можливо, й авторів глос на берегах пам'яток Київської Русі.

До того ж, характеризуючи особливості взаємодії мови й культури, окреслюючи джерела лінгвокультурології, предмет їі дослідження тощо, вважаємо, що, крім згаданих авторкою В. фон Гумбольдта й О. Потебні, доречно було б глибше заглянути у витоки цієї науки, оскільки в Аристотеля й інших давніх філософів знаходимо чимало зауваг про зв'язок мови з духом і культурою народу.

У розвідці В. Котович слушно зауважує, що «лінгвокультурологічний аспект ономастичних досліджень - це мовний (лексико-семантичний, структурно-словотвірний, етимологічний, синхронно-діахронний, стратиграфічно-просторовий) + культурологічний (матеріально-духовний, соціально-, етно- та національноорієнтований) аналіз назви кожного населеного пункту. За такого підходу історія має відповісти на питання - коли?, географія - де?, лінгвістика - як?, а культура дає змогу з'ясувати - чому номінація поселень людиною здійснювалася так, а не по-іншому» (с. 51).

Дослідниця окреслює методичний інструментарій пропонованої праці, покликаної схарактеризувати й описати ойконіми як багатошарові одиниці, наділені своєрідною семантикою; подає характеристику використовуваних методів дослідження онімного матеріалу тощо. «Творення оніма - особливий спосіб кодування мовно-культурної інформації» (с. 67), тож авторка уточнює зміст термінів код, ономастичний код, а також уводить в обіг нові терміни, як-от: ойкокультуронім, астіокультуронім, зауважуючи, що стрижневими елементами терміна на позначення основної одиниці ономастико-культурологічних досліджень має бути лексема з компонентами онім- та культуро-. 
Ономастичний та лінгвокультурологічний аналіз ойконімного простору України авторка рецензованої праці здійснює головно на матеріалі астіонімів, наголошуючи, що їх вибір не був випадковим. «Назви міст: 1) культуроємні, «являють собою сукупність окультурених уявлень про картину світу певного соціуму: про природні об'єкти, артефакти, явища, виокремлені в ній (природі), дії та події, ментофакти й належні цим сутностям просторово-часові та якісно-кількісні виміри»; 2) репрезентують культуру назвотворення всієї України, а не тільки окремого іiі регіону; 3) ще не були об'єктом комплексних ономастико-лінгвокультурологічних студій» (с. 68).

Далі В. Котович зазначає, що «важливим компонентом ономастико-культурологічного розгляду назви міського поселення $є$ окреслення, структурування та моделювання лінгвокультурологічного портре$m a$ астіоніма. Він дає змогу якнайповніше об'єктивувати імпліцитні соціальні та культурно-національні характеристики назви міста» (с. 70) та цитує В. Маслову, яка запропонувала лінгвокультурологічний портрет астіонімів, аналізуючи назви малих міст Вітебщини та здійснюючи портретування за схемою: ядро, периферія (ближня і дальня) та інтерпретаційна (образна) зона.

Лінгвокультурологічний портрет кожного 3 астіонімів сучасної України структурований в дослідженні В. Котович у такий спосіб: «ядерна зона (теперішня назва міста, його локалізація); ближня периферія (генеза астіоніма); дальня периферія (характеристика етимона); інтерпретаційна зона (контроверсійні тлумачення, народна етимологія, конотоніми, дескрипції (дескрипція - описова конструкція, яку зрідка вживають замість офіційної назви міста), дотична до назви енциклопедична інформація тощо) (с.70). Авторка так вмотивовує обрану нею схему лінгвокультурологічного портретування: «Білорська вчена акцентує насамперед увагу на астіонімі як на результаті когнітивної діяльності людини» (с. 71), тоді як для ï праці «найактуальнішим є розгляд оніма в контексті його відповідності засадам культури назовництва кожної епохи» (с. 71).

Розгляд другого та третього розділів монографії засвідчує слушність твердження С. Вербича про те, що «походження назв поселень, або ойконімів, <> вимагає від дослідника не лише відповідної лінгвістичної кваліфікації, а й грунтовних знань місцевої історії та географії, адже без урахування як мовних, так і позамовних чинників постання тієї чи тієї назви села, міста, містечка складно правильно визначити іï словотвірний тип, розкрити доонімну (апелятивну) семантику, простежити становлення ойконіма від початку його виникнення до 
наших днів, з’ясувати первинність чи вторинність досліджуваної назви щодо контактного топоніма тощо. Крім цього, важливо розуміти, що ойконіми, виникаючи в різні періоди історії певного регіону, відбивають у своїй формі мовні риси місцевого населення того часу, які не завжди збережені навіть у теперішньому діалектному словникові, i для їх відновлення потрібно здійснити докладний етимологічний аналіз, залучивши споріднені факти апелятивного й онімного рівня з суміжних і віддалених ареалів. Необхідно також пам'ятати, що наукове тлумачення ойконіма здебільшого відрізняється від так званої народної етимології, що часто грунтується на випадковому зближенні пояснюваної назви зі співзвучною загальною лексемою, яка, проте, не має жодного стосунку до твірної ойконімооснови» ${ }^{1}$.

У другому розділі «Типологія онімного коду астіоніма» В. Котович моделює лінгвокультурологічні портрети українських астіонімів-репрезентантів антропонімного індивідуального, антропонімного групового, меморіального, гідронімного, мікротопонімного, оронімного, хоронімного, ергонімного кодів. Проведений аналіз дає змогу дослідниці простежити генезу, особливості функціонування, культурно-історичну та національно-етнічну зумовленість кожної з назв міст України. Зауважимо, що астіоніми антропонімного коду - це найбільш чисельна та культуромістка група назв. Аналіз цих астіокультуронімів дав підстави авторці стверджувати, що значна частина астіонімів мотивована відомими або реконструйованими давньослов'янськими іменами-композитами, давніми відкомпозитними іменами та «несправжніми композитами», християнськими іменами, однак найбільше відантропонімних астіонімів утворено від відапелятивних антропонімів. Ці назви різняться своїми темпоральними та локативними параметрами, засобами та способами деривації, характером етимонів, а також демонструють багатство давнього антропонімікону та його прив'язаність до українського мовного грунту.

Стрижнева ознака астіокультуронімів меморіального коду, як стверджує дослідниця, - ідеологічна маркованість; гідронімного - кореляція між прозорістю / затемненістю гідроніма-етимона та назвою поселення; мікротопонімного - втілення в назві міста імені невеликого географічного об'єкта, надійно збереженого в пам'яті людини-номінатора. Оронімний, хоронімний та ергонімний коди засвідчено не-

${ }^{1}$ Вербич С. О. Нова праця з української ойконімії. Українська мова. 2013. № 4. C. 144. [Рец. на]: Котович В. Походження назв населених пунктів Дрогобиччини (наукові версії). Дрогобич: Посвіт, 2012. 88 с. 
великою кількістю назв-реперезентантів, однак вони «демонструють національний характер, історичну та географічну зумовленість, етнічну та топографічну умотивованість» (с. 243).

Третій розділ дослідження має назву «Типологія апелятивного коду астіоніма». У ньому авторка зосереджує увагу на аналізі назв поселень, що $є$ репрезентантами ландшафтно-артефактного, локально-етнічного, службового та символіко-світоглядного кодів.

Декодуючи (розшифровуючи) апелятивний код астіонімів України, дослідниця акцентує, що в таких назвах «збережено чимало мовних реліктів, які слугують ключем до пізнання специфіки менталітету людини-назвотворця» (с. 253); аналізує астіокультуроніми 3 питомими апелятивами / географічними термінами в основі та поодинокі астіокультуроніми з іншомовними, зазвичай, давньогрецькими основами або компонентами, що демонструють контакти українців з іншими етносами, засвідчують здатність мови використовувати елементи інших топонімотвірних систем задля свого розвитку.

Здійснений у третьому розділі аналіз дає підстави В. Котович стверджувати, що «астіокультуроніми апелятивного коду зберігають у своїх основах лексеми, які визначають смисловий зміст назви поселення, демонструють багату історичну, географічну світоглядну інформацію, <> експлікуючи відомості про природні особливості місцевості, про об'єкти, створені людиною, містять давній пласт лексики, рідко коли вживаний (а то й не вживаний) сьогодні, - народну географічну термінологію» (с. 310$)$.

Характеристика астіокультуронімів, які є представниками локально-етнічного та службового кодів, засвідчує, що ойконіми нерідко зберігають етнічні, локальні, професійні ознаки поселенців. Назви міст-репрезентантів символіко-світоглядного коду теж містять у собі цікавий культурологічний елемент, позаяк добиралися у такий спосіб, щоб розповісти, чим живе і житиме місто та які в нього пріоритети (c. 312).

У четвертому розділі «Ойконімний простір України як репрезентант засадничих лінгвокультурологічних категорій», В. Котович аналізує час та простір як визначальні аспекти людської свідомості, що відображені в ойконімах і створюють глибоку та неповторну для кожного етносу мовну картину світу; досліджує астіоніми наділені сакральною символікою та зауважує, що «від найдавніших часів і до сьогодення більшість із розглянутих тут ойкокультуронімів є свідками християнських чеснот людини-номінатора, людини, яка хоче не тільки назвати заселений об'єкт, але й відобразити в назві свій духов- 
ний світ» (с. 359); описує відображення категорії образності в українському ойконіміконі; розглядає астіоніми як джерело постання символів, що згодом знайшли своє втілення на гербах, емблемах, інших атрибутах населених пунктів.

Здійснене дослідження дало підстави авторці монографії висновувати про ойконімний простір України як лінгвокультурний феномен, одиниці якого слугують джерелом пізнання культури народу, його менталітету та національного характеру. Вважаємо, що розвідка Віри Василівни Котович буде корисною не тільки для дослідників української мови, а й для всіх, хто цікавиться проблемами української ойконімії. 